\title{
Farmers' practices, utilization, conservation and marketing of Bambara groundnut (Vigna subterranea (L.) Verdc.) in Dosso Region, Western Niger
}

\author{
Abdou Razakou Ibrahim • Alexandre Dansi • Mahamadou Salifou • \\ Abdou Ousmane $\cdot$ Ali Alzouma $\cdot$ Wazir Alou
}

Received: 30 November 2017/ Accepted: 18 June 2018/Published online: 5 July 2018

(C) The Author(s) 2018

\begin{abstract}
Bambara groundnut (Vigna subterranea (L.) Verdc.) is one of the important legume crop grown in marginal soils of sub-Saharan Africa. Despite its importance in food security and income generation for small scale farmers, it remains as a neglected and underutilized crop and the productivity is very low in the field due to the lack of improved varieties and lack adequate farming practices. Thus, the aim of this study is to investigate all aspects related to its production including source of seeds supply and farmers management practices, utilization, conservation and marketing. The results revealed that in this Region of Western Niger Bambara groundnut was mainly produced by female (95\%) compared to male (5\%).
\end{abstract}

\footnotetext{
A. R. Ibrahim $(\varangle) \cdot$ M. Salifou

Department of Rain Fed Crop Production, National Agricultural Research Institute of Niger (INRAN), Niamey, Niger

e-mail: a.byerima@yahoo.fr
}

\section{A. Dansi}

Laboratory of Biotechnology, Genetic Resources and Plant and Animal Breeding (BIORAVE), Faculty of Sciences and Technology of Dassa, Polytechnic University of Abomey (UPA), Dassa, Benin

A. Ousmane · W. Alou

National Extension Services, Ministry of Agriculture and Livestock of Niger, Niamey, Niger

\section{A. Alzouma}

School of Rural Development, Ministry of Agriculture and Livestock of Niger, Niamey, Niger
Farmers use their own recycled seed $(80 \%)$ which is the main source followed by provision of recycled seeds by relatives (5\%) and purchasing from the local market $(15 \%)$. Also, this finding shows that there is a lack of adequate farming practices and the crop is mostly produced on inherited land without any inputs as reported by $80 \%$ of the respondents. Mono-cropping is mainly practiced by $97 \%$ of farmers while a few of them do rotation (2\%) and most of pre and postharvest handling technologies are traditional. The most important traits preferred by Bambara farmers is seed colour (cream color), followed by high grain yield, early maturity and cooking ability according to the respondents with $98,92,88$ and $72 \%$ respectively. Several features have to be taking into account in order to promote Bambara nut including its ability to do well in harsh conditions, its nutritional benefits, and its ability to fix nitrogen, thereby increasing soil fertility in mixed cropping systems.

Keywords Bambara groundnut (Vigna subterranea (L.) Verdc.) neglected and underutilized crop · Farmers' practices · Utilization · Conservation · Marketing

\section{Introduction}

Bambara groundnut (Vigna subterranea (L.) Verdc.) is the third most important food legume crop in semi- 
arid Africa in terms of production and consumption after groundnut (Arachis hypogaea L.) and cowpea (Vigna unguiculata (L.) Walp.) (Aremu et al. 2006). The crop is grown by subsistent farmers under traditional low input agricultural systems. It is a source of revenue for subsistence farmers and provides fodder for livestock and it is rich in protein. This crop is also rich in carbohydrates and lysine (Ngwako et al. 2013) and hence constitutes a balanced diet to the rural people that consume it as a sole or mixed with other meals. The leguminous plant is mainly grown for its underground seeds, which are eaten fresh, semi-ripe or as pulse when dry and mature or ground into flour for later use (Toure et al. 2012). Its importance for human consumption was reported by many authors (Berchie et al. 2010; Severin and Yao 2011; Issa et al. 2014). Anyika et al. (2009) reported that combined protein of legumes and cereals may be better than casein or other animal sources. It also contributes to the soil fertility through biological nitrogen fixation making it beneficial in crop rotations and intercropping, hence farmers do not normally apply chemical nitrogen fertilizers to Bambara groundnut (Mkandawire 2007).

So far, 1815 accessions of Bambara groundnut are held by International Institute of Tropical Agriculture (IITA) in Nigeria where most of the material has been characterized or evaluated (Goli 1995). The Institute of Research for Development (IRD) in France also holds about 1000 accessions of Bambara groundnut as reported by Somta et al. (2011).

About 55,228 ha of Bambara groundnut are grown in Niger; with a mean production of $23,144 \mathrm{t}$ metric annually and an average yield of $405 \mathrm{~kg} / \mathrm{ha}$ (INS 2014). The production trend of Bambara nut shows a significant improvement with about $10 \%$ increase in area planted and 4\% increase in yield from 2007 to 2014 (Fig. 1). Located in Western part of the country, Dosso Region is the most important production area of Bambara nut (68\%) followed by Tillaberi (12\%), Maradi (9\%), Zinder (6\%) and Tahoua (4\%) (Fig. 2). The grains are consumed when boiled or burst as well as flour for infant nutrition while the fodder is used for animal feeding. It plays a key role in cropping system by improving soil fertility management.

Despite its importance, Bambara groundnut is considered as neglected and underutilized crop, the reason that to date no research activities were undertaken by scientists. Nevertheless, it continues generating incomes for small scale farmers (women), so that the lack of interest by researchers will cause in long term serious genetic erosion of this crop. Also, to date no improved seeds and adapted agronomic practices were developed and disseminated towards farmers. In order to improve farmers' practices we need to understand how farmers use their own indigenous knowledge in cultivating Bambara groundnut production. Thus, the objectives of this study were (1) to identify Bambara nut producers related to gender, (2) to investigate source of seeds supply and farmers practices, (3) to understand traits preferred by farmers, use and consumption, and marketing aspect of Bambara groundnut products.

\section{Materials and methods}

The study was undertaken between June and July 2015. A total of 304 Bambara producers (female and male) were randomly chosen and surveyed in Dosso Region of western Niger in 2015 (Fig. 3). Structured questionnaires were used to collect information on source of seed, cultural practices, farming systems, landraces grown, traits preference, socio-economic factors, pre and post-harvest handling, utilization and constraints in Bambara nut production in western Niger region. Farmers to be interviewed were picked randomly ensuring the whole coverage of the area with the assistance of Agricultural extension officers. In addition to the structured questionnaire, focus group discussions were conducted in the districts of Doutchi, Dan Kassari, Guecheme and Wassangou. Table 1 gives the lists of villages sampled and number producers interviewed.

Descriptive statistical analysis was used to determine percentages among various parameters investigated in this study.

\section{Results and discussions}

Percentage of gender in Bambara groundnut production

The results in Fig. 4 show that in Dosso Region of Western Niger Bambara groundnut was mainly produced by female (95\%) compared to male $(5 \%)$. The majority of these women are illiterate meaning not having any formal education. These findings are in 
Fig. 1 Evolution of area, production and yield of Bambara groundnut during 10 years in Niger

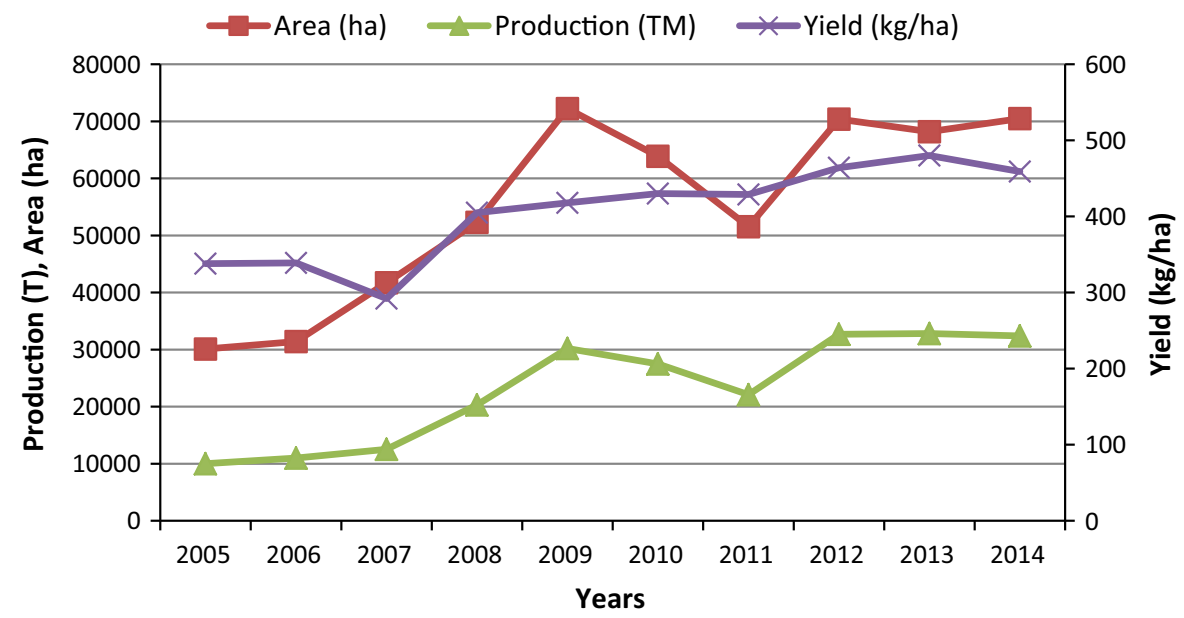

Fig. 2 Area, production and yield of Bambara groundnut per region in 2014

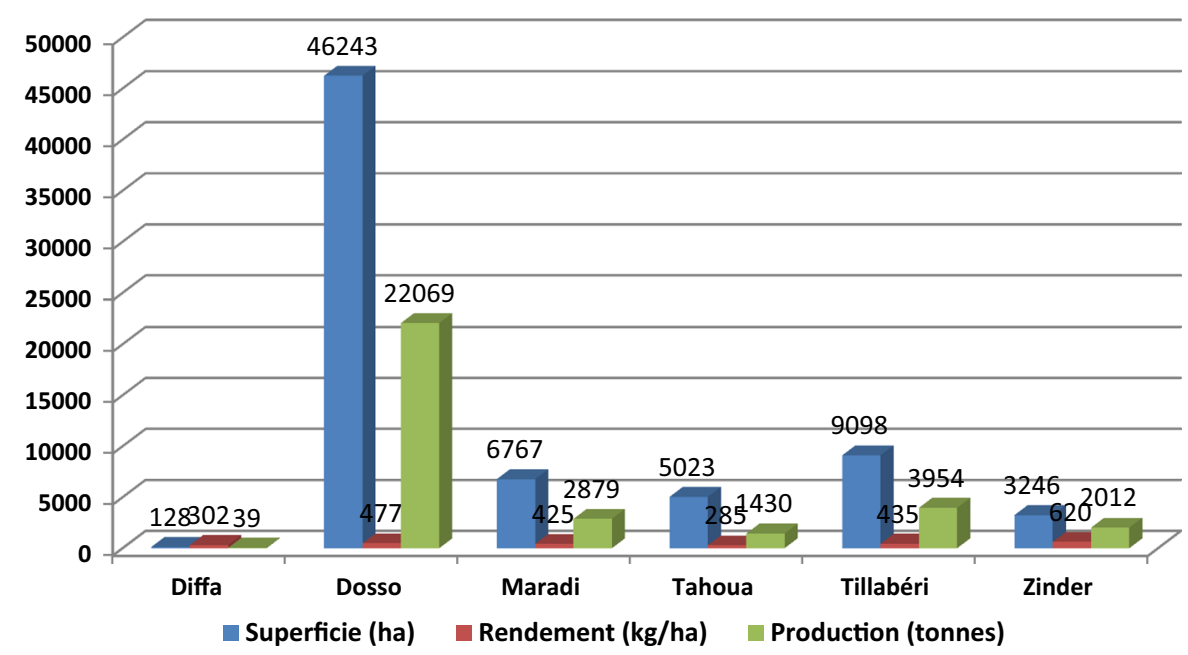

agreement with the results of Hillocks et al. (2012) who reported that in Zimbabwe the crop is grown mainly by women. Also, Berchie et al. (2010) reported that in Ghana women $(63 \%)$ dominated men $(37 \%)$ in Bambara groundnut production. This explains the reason that the "Arawa" people living in this region are calling it in Hausa language "goudjia matta" meaning women groundnut. In addition, Wasula et al. (2014), reported that in Kakamega County in Kenya, one of the perception with the highest mean rank is Bambara nut production is entirely a female activity and men should forget about growing it. In contrary, Yaya et al. (2013) reported that the Gnaraforo, an ethnic group of Ferkessedougou Bambara grounnut was cultivated only by men. These results suggest that Bambara groundnut production depends on the ethnic groups and local traditions.
Sources of seed supply

Seed is one of the important production factors that affect volume of production for Bambara groundnuts. Lack of seed was cited by $70 \%$ of the respondents as one of the challenges facing Bambara groundnut production. Seed of the crop is found with very few individuals, mostly the elderly. Use of the farmer's own recycled seed is the main (80\%) source of seed for Bambara groundnuts followed by provision of recycled seeds by relatives (5\%) and purchasing from the local market (15\%) (Table 2). Similar results were reported by Aviara et al. (2013) who stated that in North Eastern Nigeria Bambara farmers grown seeds selected and maintain by the local community over a long period. 


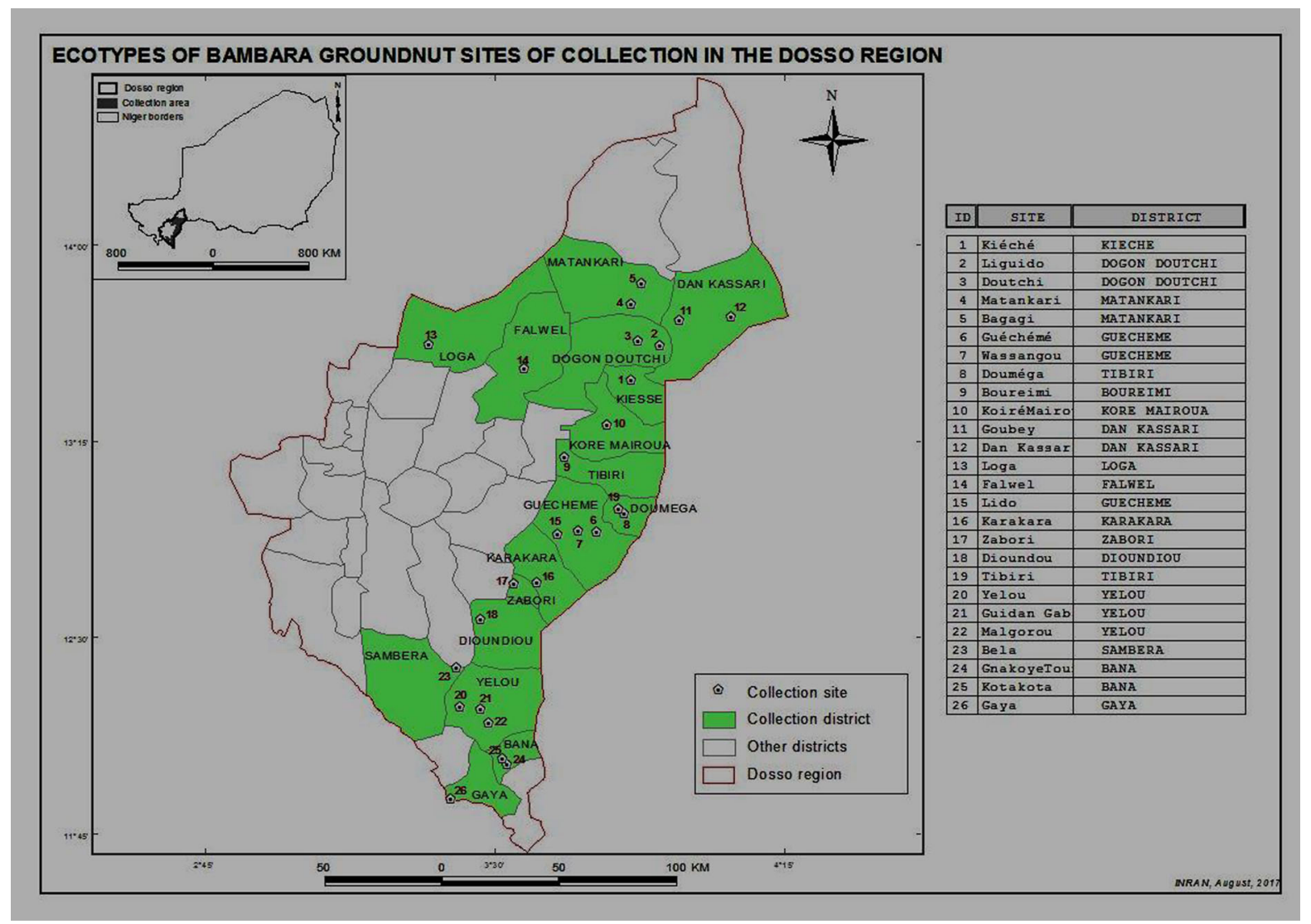

Fig. 3 Collecting areas/sites of Bambara groundnut ecotypes in Dosso Region of Western Niger

However, the dominant seed found in this region is the one of cream color which is much appreciated (Fig. 5).

\section{Farmers' practices}

The results revealed in Fig. 6 that Bambara farmers did not use any improved seed varieties as stated above, no fungicides or pesticides were applied, but some of them used organic manure (20\%), as well as chemical fertilizer (2\%). This shows that there is a lack of adequate cultural practices and the crop is produced without any inputs. This is in consistent with a recent study of Korir et al. (2011) stating that fertilizers and any other agrochemical were scarcely used by Bambara groundnut farmers in Western Kenya.

Farmers cultivated Bambara based on their indigenous knowledge. They used the same spacing of groundnut which is $40 \mathrm{~cm} \times 15 \mathrm{~cm}$ the equivalent of a population density of about 166,667 hole/ha to plant
Bambara groundnut and the majority of them (94.2\%) preferred hand weeding. Several pests and diseases that farmers experienced in this region were reported in Table 3 with grasshoppers causing completely the loss of production (90-100\%) followed by weevils $(80 \%)$.

The land allocation for Bambara production and cropping system are presented in Table 4, a higher percentage of farmers $(80 \%)$ cultivated the crop on the family land while a moderate percentage of farmers $(12 \%)$ used their own land. Also, a lower percentage of $8 \%$ was observed for farmers hiring the land. This finding is similar to that of Akpalu et al. (2013) who reported that $87 \%$ of Bambara groundnut farmers inherited their farmlands.

The average size of these lands was 0.8 ha with a minimum of 0.2 ha and a maximum of 2 ha. The results show that $97 \%$ of Bambara farmers used mono cropping while few of them intercropped (1\%) or did rotation $(2 \%)$ with major crops such as millet and 
Table 1 Lists of village sampled and number of producers interviewed

\begin{tabular}{|c|c|c|c|c|c|c|c|}
\hline \multicolumn{8}{|c|}{ Dosso region } \\
\hline \multirow[t]{2}{*}{ No. } & \multirow[t]{2}{*}{ Villages sampled } & \multicolumn{2}{|c|}{ Number of producers interviewed } & \multirow[t]{2}{*}{ No. } & \multirow[t]{2}{*}{ Villages sampled } & \multicolumn{2}{|c|}{ Number of producers interviewed } \\
\hline & & Female & Male & & & Female & Male \\
\hline 1 & Kieche & 14 & 0 & 14 & Falwel & 10 & 0 \\
\hline 2 & Liguido & 13 & 0 & 15 & Lido & 8 & 0 \\
\hline 3 & Doutchi & 4 & 3 & 16 & Karakara & 11 & 0 \\
\hline 4 & Matankari & 8 & 0 & 17 & Zabori & 12 & 0 \\
\hline 5 & Bagagi & 12 & 0 & 18 & Dioundou & 9 & 0 \\
\hline 6 & Guecheme & 35 & 0 & 19 & Tibiri & 13 & 0 \\
\hline 7 & Wassangou & 18 & 0 & 20 & Yelou & 14 & 0 \\
\hline 8 & Doumega & 10 & 0 & 21 & Guidan Gaba & 11 & 0 \\
\hline 9 & Boureimi & 4 & 2 & 22 & Malgorou & 5 & 2 \\
\hline 10 & Koire Mairoua & 12 & 3 & 23 & Bela & 3 & 2 \\
\hline 11 & Goubey & 7 & 0 & 24 & Gaya & 4 & 1 \\
\hline 12 & Dan Kassari & 39 & 0 & 25 & Gnakoye Tounga & 3 & 1 \\
\hline 13 & Loga & 8 & 0 & 26 & Kotakota & 2 & 1 \\
\hline \multicolumn{2}{|c|}{ Sub total } & 184 & 8 & & & 105 & 7 \\
\hline \multicolumn{2}{|c|}{ Total } & 304 & & & & & \\
\hline
\end{tabular}

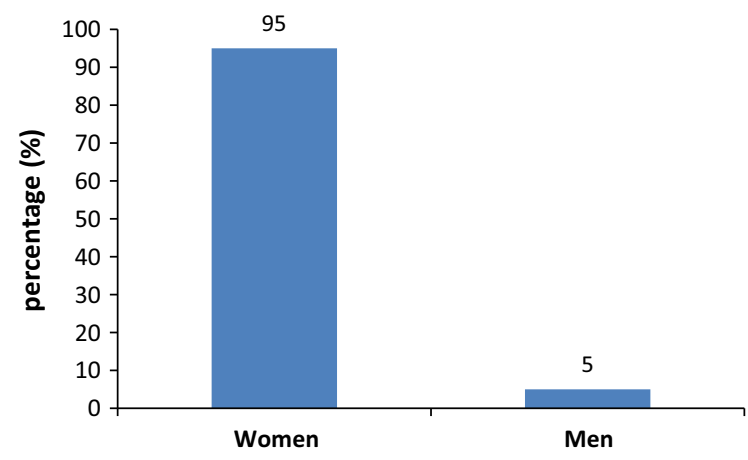

Fig. 4 Percentage of gender in Bambara groundnut production

Table 2 Sources of seeds supply for Bambara farmers

\begin{tabular}{lc}
\hline Sources & $\begin{array}{l}\text { Bambara farmers' } \\
\text { percentage }(\%)\end{array}$ \\
\hline Farmer's own recycled seed & 80 \\
Recycled seeds from relatives & 5 \\
Seeds from local market & 15 \\
\hline
\end{tabular}

sorghum. These findings revealed that farmers grown Bambara in marginal land because women who were the main producers do not have access to land. Similar results were found by Toure et al. (2012) in the Northern part of Ivory Coast where monoculture is practiced by $54 \%$ of farmers while $46 \%$ of farmers intercropped Bambara with other crops such as groundnut, maize, cowpea as well as yam. However, the findings of Alhassan and Egbe's (2013) revealed that $65.8 \%$ of Bambara groundnut farmers practiced intercropping in Benue and Kogi States of Nigeria.

Bambara groundnut was harvested at maturity by pulling or lifting the plant according the respondents and sun drying of pods is mainly practiced. The drying pods were detached from the roots and collected manually. Farmers had their own traditional ways to crash pods. More than ninety percent $(90 \%)$ of them use mortar and pestle to crush dry pods.

\section{Conservation and utilization of Bambara groundnut}

The conservation of Bambara nut diversity is based on indigenous knowledge because most of seeds were stored in traditional granaries, in jute bags and empty containers filled with sand or hash in order to prevent weevils' attacks as reported by $95 \%$ of the farmers. The findings of Baoua et al. (2014) confirms weevil's 


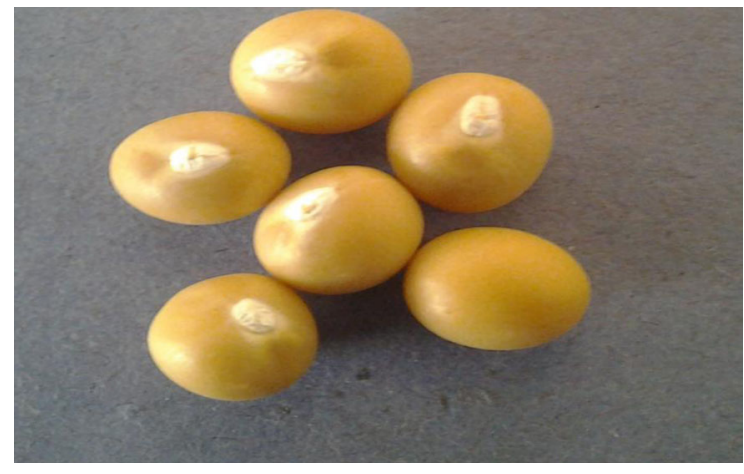

Fig. 5 Seeds of Vigna subterranea with cream color

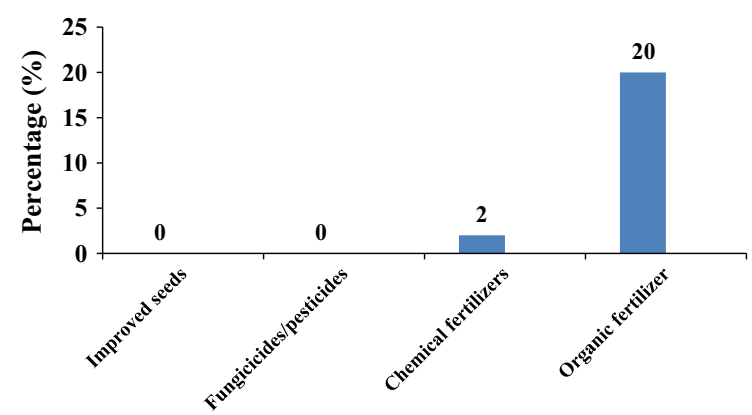

Fig. 6 Percentage of Bambara farmers using improved seeds, agrochemical inputs and organic fertilizer

Table 3 Pests and diseases observed in Bambara groundnut fields

\begin{tabular}{lll}
\hline Pests/diseases & Description & $\begin{array}{l}\text { Percentage of damage } \\
\text { in Bambara (\%) }\end{array}$ \\
\hline Pests & Aphids & 20 \\
& Termites & 15 \\
& Grasshoppers & $90-100$ \\
& Larvae & 30 \\
& Weevils & 80 \\
Diseases & Leaf spot & 25 \\
\hline
\end{tabular}

attacks revealing that the percentage of Callosobruchus maculatus emergence holes per 100 seed increased from 51 to $135 \%$ in woven bags (control) while their massive numbers increase with a mean of 309 and 251 adults per $500 \mathrm{~g}$ in heavily and lightly infested Bambara grain, respectively. Also, this result corroborates the findings of Issa et al. (2014) who reported that in Niger farmers used chemicals in
Table 4 Land allocation for Bambara production and cropping system

Percentage $(\%)$ of farmers

$\begin{array}{lr}\text { Land allocation and size } & \\ \text { Family land used (0.4-0.6 ha) } & 80 \\ \text { Own land used (0.4-2 ha) } & 12 \\ \text { Hired land used (0.2-0.8 ha) } & 8 \\ \text { Cropping system } & \\ \text { Mono cropping } & 97 \\ \text { Intercropping } & 1 \\ \text { Rotation } & 2\end{array}$

addition to these traditional methods to store Bambara groundnut seeds.

Fresh and dry Bambara groundnuts are consumed at household level in the following ways:

1. loubatou (boiled fresh pods decorticated nuts),

2. dawalé (decorticated nuts which are roasted),

3. béroua, this is decorticated nuts processed and transformed into small grains,

4. gabda,

5. touwo,

6. kalapaté goudjia

7. maringuidé,

Loubatou and dawalé are reported by $83 \%$ of respondents as the most important end products of Bambara preferred by consumers. Dawale is sold by young ladies along the streets and on market in Doutchi district at all the moment (day and night). Loubatou is sold by both old women and young ladies in the capital mainly during the raining season (August to early September) while in the village famers use it as meal for the night before the maturity of staple food crops. Also, at Matankari village farmers reported that they use Bambara flour to make spaghetti. The main constraint as reported by the majority of farmers (75\%) was the cooking time. Some of farmers use soaking methods (overnight) or use bicarbonate in order to overcome this situation. The fodder of Bambara plant is used for animal feeding. 
Traits preferred by farmers

The traits preferred by Bambara farmers are reported in Table 5 below. According to this table the most important trait for Bambara farmers is seed colour (98\%), followed by high grain yield (92\%), early maturity (88\%) and cooking ability (72\%). This shows the ability of Bambara groundnut to cope with some biotic (pests and diseases attacks) and abiotic stress (drought). This result is not in agreement with the findings of Pungulani et al. (2012) who stated that the most important traits preferred by Bambara farmers in Malawi were plant vigour followed by maturity period and grain Size while seed colour was the least.

\section{Marketing of Bambara groundnut}

Bambara groundnuts are sold in the following forms, fresh mature pods, cooked fresh mature pods, dry grains and dry pods. From the study it was reported that $95 \%$ (women) of the respondents had not sold green Bambara groundnut to anyone. All that they produced was for home consumption while 5\% (men) of the respondents had sold dry Bambara nuts. The results revealed that Bambara groundnuts are mainly

Table 5 Farmer's Bambara preference in Dosso Region

\begin{tabular}{|c|c|c|c|}
\hline Characteristics & Description & Frequency & $\begin{array}{l}\text { Percentage } \\
(\%)\end{array}$ \\
\hline \multirow[t]{2}{*}{ Early maturity } & Yes & 268 & 88 \\
\hline & No & 36 & 12 \\
\hline \multirow{2}{*}{$\begin{array}{l}\text { Seed colour (cream } \\
\text { colour) }\end{array}$} & Yes & 298 & 98 \\
\hline & No & 6 & 2 \\
\hline \multirow[t]{2}{*}{ Grain size } & Yes & 201 & 66 \\
\hline & No & 103 & 34 \\
\hline \multirow[t]{2}{*}{ Cooking ability } & Yes & 219 & 72 \\
\hline & No & 85 & 28 \\
\hline \multirow[t]{2}{*}{ Storage ability } & Yes & 128 & 42 \\
\hline & No & 176 & 58 \\
\hline \multirow[t]{2}{*}{ Drought resistance } & Yes & 170 & 56 \\
\hline & No & 134 & 44 \\
\hline \multirow[t]{2}{*}{ Pest resistance } & Yes & 170 & 56 \\
\hline & No & 134 & 44 \\
\hline \multirow[t]{2}{*}{ Disease resistance } & Yes & 164 & 54 \\
\hline & No & 140 & 46 \\
\hline \multirow[t]{2}{*}{ High grain yield } & Yes & 280 & 92 \\
\hline & No & 24 & 8 \\
\hline
\end{tabular}

produced for household consumption and there is limited trading taking place. Thus, there is no formal marketing for the crop and men regard it as unprofitable and hence it is left to be grown by women since they are the ones responsible for food preparation. The results are in concordance with the findings of Adzawla et al. (2016) reporting that there was no market that is solely marked for the marketing of Bambara groundnut in Northern Ghana.

\section{Conclusion}

Bambara groundnuts are mainly grown by women (95\%) on marginal areas of the field after planting other staple food crops like millet, sorghum, cowpea and groundnuts. Bambara famers used their own recycled seeds (80\%) and the cultivation is based on indigenous knowledge. The main cropping system observed is monoculture practiced by $97 \%$ of farmers.

However, $2 \%$ of famers used rotation in order to benefit cereals with remaining nitrogen fixed by Bambara groundnut in the soil. Traditional methods were used for harvesting and storing seeds of this crop and Loubatou and dawale are reported by $83 \%$ of respondents as the most important end products of Bambara that consumers preferred. This study shows that farmers preferred Bambara with cream color $(98 \%)$, high yield $(92 \%)$, early maturity $(88 \%)$ and less cooking time (72\%). There is no formal marketing for Bambara groundnut. The most important production constraint of Bambara groundnut production is the lack of improved varieties, suggesting that further breeding is needed to enhance productivity. In order to boost the productivity of Bambara groundnut future research should be focused on dissemination of improved varieties and adequate management practices, as well as facilitation to women access to inputs, lands and credits.

Acknowledgements The author extends its gratitude to the WAAPP/PPAAO for supporting this research under the project «Improving the productivity of Bambara groundnut in Niger $\gg$ and also would like to thank research partners for providing guidance on modalities of conducting the study.

\section{Compliance with ethical standards}

Conflict of interest The authors declare that they have no conflict of interest. 
Open Access This article is distributed under the terms of the Creative Commons Attribution 4.0 International License (http:// creativecommons.org/licenses/by/4.0/), which permits unrestricted use, distribution, and reproduction in any medium, provided you give appropriate credit to the original author(s) and the source, provide a link to the Creative Commons license, and indicate if changes were made.

\section{References}

Adzawla W, Donkoh SA, Nyarko G, O'Reilly P, Mayes S (2016) Use patterns and perceptions about the attributes of Bambara groundnut (Vigna subterranea (L.) Verdc.) in Northern Ghana. Ghana J Sci Technol Dev. http://gjstd.org

Akpalu MM, Atubilla IA, Oppong-Sekyere D (2013) Assessing the level of cultivation and utilization of Bambara groundnut (Vigna subterranea (L.) Verdc.) in the sumbrungu community of Bolgatanga, Upper East Region, Ghana. IJPAES 3(3):68-75

Alhassan GA, Egbe MO (2013) Participatory rural appraisal of Bambara groundnut (Vigna subterranea (L.) Verdc.), production in southern Guinea Savanna of Nigeria. Agric Sci 1(2):18-31

Anyika JU, Obizoba IC, Nwamarah JU (2009) Effect of processing on the protein quality of African Yam bean and Bambara groundnut supplemented with sorghum or crayfish in rats. Pak J Nutr 8(10):1623-1628. https://doi.org/10. 3923/pjn.2009.1623.1628

Aremu MO, Olaofe O, Akintayo ET (2006) Chemical composition and physicochemical characteristics of two varieties of Bambara groundnut (Vigna subterrenea). J Appl Sci 6:1900-1903. https://doi.org/10.3923/jas.2006.1900.1903

Aviara NA, Lawal AA, Atiku AA, Haque MA (2013) Bambara groundnut processing, storage and utilization in north eastern Nigeria. Cont J Eng Sci 8(1):28-36. https://doi.org/ 10.5707/cjengsci.2013.8.1.28.36

Baoua IB, Amadou L, Baributsa D, Murdock LL (2014) Triple bag hermetic technology for postharvest preservation of Bambara groundnut (Vigna subterranea (L.) Verdc.). J Stored Prod Res 58:48-52. https://doi.org/10.1016/j.jspr. 2014.01.005

Berchie JN, Adu-Dapaah HK, Dankyi AA, Plahar WA, NelsonQuartey F, Haleegoah J (2010) Practices and constraints in Bambara groundnuts production, marketing and consumption in the Brong Ahafo and Upper-East Regions of Ghana. J Agro 9(3):111-118. https://doi.org/10.3923/ja. 2010.111.118

Bonny SB, Dje Y (2011) Variabilité morphologique et agronomique des variétés traditionnelles de voandzou (Vigna subterranea (L.) Verdc.) de Cote d'Ivoire. J Appl Biosci $1: 2820-2835$
Goli AE (1995) Characterization and evaluation of IITA's Bambara groundnut collection. In: Begemann JH, Mushonga $\mathbf{J}$ (eds) Proceedings of the workshop on conservation and improvement of Bambara groundnut (Vigna subtarranea (L.) Verdc.). International Plant Genetic Resources Institute (IPGRI)

Hillocks RJ, Bennett C, Mponda OM (2012) Bambara groundnut: a review of utilization, market potential and crop improvement. Afr Crop Sci J 20(1):1-6

Issa AH, Bakasso Y, Mayaki ZA, Doumma A, Boucar IM (2014) Diagnostic participatif de la diversité de morphotypes et des connaissances locales en matière de culture du Voandzou (Vigna subterranea L.) au Niger. Int J Innov Appl Stud 9(4):1915-1925

Korir MK, Serem AK, Sulo TK and Kipsat MP (2011) A stochastic frontier analysis of Bambara groundnut production in Western Kenya. In: Proceedings of the 18th international farm management congress, Methven, Canterbury, IFMA18-Theme vol 3, pp 74-80. www. ifmaonline.org

Mkandawire C (2007) Review of Bambara groundnut (Vigna subterranean (L.) Verdc.) production in sub-Sahara Africa. Agric J 2:464-470

National Statistical Institute of Niger (INS) (2014) Le Niger en chiffres. Ministry of Planning, Territory Management and Community Development, Niamey, November 2014. http://www.ins.ne. e-mail: ins@ins.ne

Ngwako S, Balole TV, Malambane G (2013) The effect of irrigation and planting date on the growth and yield of Bambara groundnut landraces. Int J Agric Crop Sci 6(3):116-120

Pungulani L, Kadyampakeni D, Nsapato L, Kachapila M (2012) Selection of high yielding and farmers' preferred genotypes of Bambara nut (Vigna subterranea (L.) Verdc) in Malawi. Am J Plant Sci 3:1802-1808

Somta P, Chankaew S, Rungnoi O, Srinives P (2011) Genetic diversity of the Bambara groundnut (Vigna subterranea (L.) Verdc.) as assessed by SSR markers. Genome 54:898-910. https://doi.org/10.1139/g11-056

Toure Y, Kone M, Tanoh HK, Kone D (2012) Agromorphological and phenological variability of 10 Bambara groundnut (Vigna subterranea (L.) Verdc.) landraces cultivated in the Ivory Coast. Tropicultural 30:216-221

Wasula SL, Wakhungu J, Palapala V (2014) Farmers' perceptions and adoption of Bambara nut production as a food security crop in Kakamega County, Kenya. Int J Disaster Manag Risk Reduct 2(1):50-62

Yaya T, Koné M, Silué S, Yatty J (2013) Prospection, collecte et caractérisation agromorphologique des morphotypes de voandzou de la zone savanicole en Côte d'Ivoire, Euro Sci J 9(24). ISSN:1857-7881 